\title{
TINJAUAN YURIDIS PENERIMAAN PESERTA DIDIK BARU DALAM SISTEM ZONASI
}

\author{
Nani Yuliani ${ }^{1}$
}

\begin{abstract}
ABSTRAK
Kebijakan zonasi ini, pada kenyataannya berbeda dengan harapan masyarakat pada umumnya. Hal ini karena masyarakat menginginkan sekolah berkualitas bagi anak-anaknya. Seperti dalam memilih sekolah hal pertama yang paling menentukan ialah kualitas sekolah dan lokasi menjadi pertimbangan yang terakhir. Selanjutnya, sekolah yang berkualitas oleh masyarakat biasa dilabeli sebagai sekolah favorit. Faktor utama dalam memilih sekolah ialah tingkat kefavoritan sekolah. Faktor tersebut bahkan mengalahkan faktor lain seperti fasilitas dan guru. Fakta tersebut menunjukkan adanya perbedaan antara masyarakat dan pemerintah melalui kebijakan sistem zonasi dalam hal pemilihan sekolah. Bukan hanya masyarakat, namun sekolah juga tidak bisa memilih siswa yang diinginkan.

Metode penelitian yang digunakan adalah penelitian hukum normatif yang bersifat deskriptif analisis, pengumpulan data dilakukan dengan menggunakan data primer dan data sekunder berupa bahan hukum primer, sekunder dan tertier sebagai data utama. Setelah data sekunder dan primer terkumpul, kemudian diadakan analisis secara kualitatif

Berdasarkan hasil analisis data, disimpulkan bahwa Permendikbud Nomor 44 Tahun 2019 sendiri sebenarnya mengandung ketidakadilan. Dalam Pasal 31 ayat (1) dan ayat (2) diatur bahwa untuk jenjang SMP dan SMA calon peserta didik baru kelas 7 (tujuh) SMP dan kelas 10 (sepuluh) SMA dilakukan dengan memprioritaskan jarak tempat tinggal terdekat ke sekolah dalam wilayah zonasi yang ditetapkan, namun jika jarak tempat tinggal calon peserta didik dengan sekolah sama, maka seleksi pemenuhan kuota atau daya tampung terakhir menggunakan usia peserta didik yang lebih tua. Seharusnya kriteria kedua yang lebih relevan setelah jarak adalah prestasi siswa. Kriteria prestasi ini akan lebih fair dibandingkan dengan kriteria usia. Faktor yang menjadi kendala PPDB dengan sistem zonasi diantaranya Sekolah favorit masih terbatas,Pemerataan kualitas pendidikan yang masih timpang dan Kurangnya sosialisasi dari pemerintah.
\end{abstract}

\section{Kata Kunci: Penerimaan, Peserta Didik Baru, Zonasi}

\footnotetext{
${ }^{1}$ Guru SMPN 2 Maja Majalengka. Email, naniyuliani21@gmail.com
} 
PRESUMPTION of LAW

Fakultas Hukum Universitas Majalengka

Volume 3 Nomor 1 April 2021

\section{A. Latar Belakang}

Pendidikan merupakan hak asasi manusia, yang memiliki peran penting dalam kehidupan bermasyarakat ${ }^{2}$. Sebagaimana tertera dalam Pasal 31 ayat (1) Undang- Undang Dasar 1945 yang menyebutkan bahwa:

"Setiap warga negara berhak mendapat pendidikan. Pelaksanaan proses pendidikan ini guna mencerdaskan dan mengembangkan moral bangsa agar menjadi lebih baik dan bermartabat. Pendidikan adalah salah satu hal penting sehingga mendorong pemerintah untuk terus meningkatkan kualitas layanan pendidikan."

Pendidikan merupakan salah satu hak yang bersifat mendasar bagi seluruh warga negara, khususnya di Indonesia. Hal tersebut sejalan dengan Pasal 28 C ayat (1) Undang-Undang Dasar Negara Republik Indonesia Tahun 1945 yang menyatakan bahwa Setiap orang berhak mengembangkan diri melalui pemenuhan kebutuhan dasarnya, berhak mendapat pendidikan dan memperoleh manfaat dari ilmu pengetahuan dan teknologi, seni dan budaya, demi meningkatkan kualitas hidupnya dan demi kesejahteraan umat manusia. Selain itu diatur juga di dalam Pasal 28 E ayat (1) Undang-Undang Dasar Negara Republik Indonesia Tahun 1945 yang menyatakan bahwa setiap orang berhak memeluk agama dan beribadat menurut agamanya, memilih pendidikan dan pengajaran, memilih pekerjaan, memilih kewarganegaraan, memilih tempat tinggal di wilayah negara dan meninggalkannya, serta berhak kembali. Pendidikan diibaratkan sebagai modal dasar dalam kebudayaan dan sebuah pondasi utama dalam membangun peradaban suatu bangsa. Sebuah kesadaran akan pentingnya pendidikan, akan menentukan kualitas kesejahteraan lahir dan batin serta masa depan masyarakatnya.

Misi pendidikan yang paling utama adalah mewariskan ilmu dari generasi ke generasi selanjutnya dengan harapan jangan sampai generasi selanjutnya tidak dapat mengenyam pendidikan yang dalam hal ini ilmu pengetahuan, tradisi dan nilai-nilai budaya yang dianut oleh Bangsa Indonesia. Namun eksistensi dunia pendidikan di Indonesia sampai saat ini masih menjadi permasalahan dikarenakan masih terdapat adanya penyimpanganpenyimpangan dalam proses belajar mengajar maupun dari dunia pendidikan itu sendiri. Untuk mengatasi masalah tersebut, pemerintah telah berupaya dalam mengurangi kesenjangan-kesenjangan dalam kehidupan di masyarakat sebagai implementasi Nawa Cita Presiden Republik Indonesia Joko Widodo. ${ }^{3}$ Salah satu kebijakan yang ditempuh oleh Kementerian Pendidikan dan Kebudayan sebagai bentuk pemerataan akses pada layanan pendidikan serta pemerataan kualitas pendidikan nasional adalah dengan menerapkan kebijakan

${ }^{2}$ Mujianto Solichin, Imama Kutsi, Implementasi Permendikbud Nomor 14 Tahun 2018 tentang Penerimaan Peserta Didik Baru Berbasis Sistem Zonasi pada Tingkat Madrasah Ibtidaiyah/Sekolah Dasar di Kecamatan Jombang, Jurnal Manajemen dan Pendidikan Islam, Vol. 5, No. 1, Juni 2019, hlm 20

${ }^{3}$ I Putu Andika Pratama dan Ketut Suardita, Pengaturan Penerimaan Peserta Didik Baru Melalui Jalur Zonasi Sekolah, Jurnal Jurnal Kertha Patrika, Vol. 41, No. 3 Desember 2019, hlm. 239 
PRESUMPTION of LAW

Fakultas Hukum Universitas Majalengka

Volume 3 Nomor 1 April 2021

sistem zonasi sekolah. Dalam hal ini telah diberlakukannya aturan baru mengenai Penerimaan Peserta Didik Baru (selanjutnya disebut PPDB) dengan memakai sistem zonasi (wilayah).

Penerimaan Peserta Didik Baru (PPDB) dilaksanakan melalui mekanisme dalam jejaring (daring/online) maupun luar jejaring (luring/offline). Untuk memudahkan calon peserta didik mengakses sekolah, diberlakukan sistem zonasi. Pengaturan ini diharapkan dapat membuat proses penerimaan berlangsung secara objektif, akuntabel, transparan, dan tanpa diskriminasi guna meningkatkan akses layanan pendidikan.

Sistem zonasi pada Penerimaan Peserta Didik Baru (PPDB) tahun 2017 diatur pada Peraturan Menteri Pendidikan dan Kebudayaan No 17 Tahun 2017 tentang Penerimaan Peserta Didik Baru (PPDB). Sistem zonasi merupakan sistem yang diberlakukan dengan penentuan zona oleh pemerintah daerah masing-masing yang wajib menerima calon peserta didik yang berdomisili pada radius zona terdekat dari sekolah dengan persentase tertentu dari total jumlah peserta didik yang diterima. Radius zona terdekat ditetapkan oleh pemerintah daerah sesuai dengan kondisi daerah masing-masing. Pada tahun 2017 sistem zonasi untuk pertama kali diterapkan dalam penerimaan peserta didik baru dan disempurnakan di tahun 2018 melalui Permendikbud Nomor 14 Tahun 2018. Kemudian Permendikbud Nomor 14 Tahun 2018 pun dicabut diganti oleh Peraturan Menteri Pendidikan Dan Kebudayaan Republik Indonesia Nomor 51 Tahun 2018 tentang Penerimaan Peserta Didik Baru Pada Taman KanakKanak, Sekolah Dasar, Sekolah Menengah Pertama, Sekolah Menengah Atas, Dan Sekolah Menengah Kejuruan. Peraturan Menteri Pendidikan dan Kebudayaan Nomor 51 Tahun 2018 dicabut dan dinyatakan tidak berlaku lagi dan penggantinya adalah Peraturan Menteri Pendidikan dan Kebudayaan Nomor 20 Tahun 2019 tentang Perubahan atas Peraturan Menteri Pendidikan dan Kebudayaan Nomor 51 Tahun 2018 tentang Penerimaan Peserta Didik Baru pada Taman Kanak-Kanak, Sekolah Dasar, Sekolah Menengah Pertama, Sekolah Menengah Atas, dan Sekolah Menengah Kejuruan, namun Peraturan Menteri Pendidikan dan Kebudayaan Nomor 20 Tahun 2019 tentang Perubahan atas Peraturan Menteri Pendidikan dan Kebudayaan Nomor 51 Tahun 2018 tentang Penerimaan Peserta Didik Baru pada Taman Kanak-Kanak, Sekolah Dasar, Sekolah Menengah Pertama, Sekolah Menengah Atas, dan Sekolah Menengah Kejuruan (Berita Negara Republik Indonesia Tahun 2019 Nomor 669), dicabut dan dinyatakan tidak berlaku lagi dan diganti dengan Peraturan Menteri Pendidikan Dan Kebudayaan Republik Indonesia Nomor 44 Tahun 2019 Tentang Penerimaan Peserta Didik Baru Pada Taman Kanak-Kanak, Sekolah Dasar, Sekolah Menengah Pertama, Sekolah Menengah Atas, Dan Sekolah Menengah Kejuruan. Peraturan Menteri Pendidikan Dan Kebudayaan Republik Indonesia Nomor 44 Tahun 2019 dicabut lagi dan dinyatakan tidak berlaku lagi dan diganti dengan Peraturan Menteri Pendidikan Dan Kebudayaan Republik Indonesia Nomor 1 Tahun 2021 Tentang Penerimaan Peserta Didik Baru Pada Taman Kanak-Kanak, Sekolah Dasar, Sekolah Menengah Pertama, Sekolah Menengah Atas, Dan Sekolah Menengah Kejuruan. 
PRESUMPTION of LAW Fakultas Hukum Universitas Majalengka

Volume 3 Nomor 1 April 2021

Solusi alternatif yang ditawarkan pemerintah adalah penerapan sistem zonasi pada penerimaan peserta didik baru (PPDB). Ketentuan sistem zonasi PPDB tahun 2021 berdasarkan Permendikbud No. 1 Tahun 2021 yang bertujuan menjamin penerimaan peserta didik baru secara objektif, akuntabel, transparan dan tanpa diskriminasi sehingga mendorong peningkatan dan pemerataan akses layanan pendidikan.

Sistem zonasi merupakan kebijakan penerimaan peserta didik baru (PPDB) yang dilakukan dengan menentukan radius zona antara sekolah dengan tempat siswa terkait berdomisili. Pelaksanaan sistem zonasi secara teknis dilakukan oleh pemerintah daerah atas pertimbangan musyawarah kerja kepala sekolah (MKKS). Sekolah berwajiban untuk menerima calon peserta didik yang berdomisili pada radius zona terdekat dengan presentase tertentu, dari total jumlah peserta didik yang akan diterima.

Pelaksanaan sistem zonasi memang penuh dengan dinamika, faktanya kebijakan tersebut, merupakan rekomendasi dari Ombudsman Republik Indonesia pada tahun 2016 kepada Kemendikbud, Kemendagri, dan Kemenag, rekomendasi ini kemudian ditindaklanjuti oleh Menteri Pendidikan dan Kebudayaan pada era Muhadjir Effendy dengan tujuan untuk menghilangkan predikat sekolah unggulan, guna mewujudkan pemerataan kualitas pendidikan di seluruh sekolah Indonesia. ${ }^{4}$ Pendaftaran PPDB dalam Pasal 12 Permendikbud Nomor 1 Tahun 2021 dilaksanakan melalui jalur sebagai berikut:

(1) PPDB untuk SD, SMP, dan SMA dilaksanakan melalui jalur pendaftaran PPDB

(2) Jalur pendaftaran PPDB sebagaimana dimaksud pada ayat (1) meliputi:

a. afirmasi;

b. perpindahan tugas orang tua/wali; dan/atau

c. prestasi

Sedangkan dalam Pasal 13 Permendikbud Nomor 1 Tahun 2021 menyatakan bahwa :

(1) Jalur zonasi sebagaimana dimaksud dalam Pasal 12 ayat (2) huruf a terdiri atas:

a jalur zonasi SD paling sedikit 70\% (tujuh puluh persen) dari daya tampung sekolah;

b jalur zonasi SMP paling sedikit 50\% (lima puluh persen) dari daya tampung sekolah; dan

c jalur zonasi SMA paling sedikit 50\% (lima puluh persen) dari daya tampung sekolah.

(2) Jalur afirmasi sebagaimana dimaksud dalam Pasal 12 ayat (2) huruf $\mathrm{b}$ paling sedikit $15 \%$ (lima belas persen) dari daya tampung sekolah.

${ }^{4}$ Agil Nanggala, Analisis Wacana Pembaharuan Kebijakan Zonasi Menteri Pendidikan Dan Kebudayaan Nadiem Makarim Sebagai Solusi Pemerataan Pendidikan Di Indonesia, Jurnal Pendidikan Kewarganegaraan Undiksha Vol. 8 No. 2 Mei, 2020, hlm 48 
PRESUMPTION of LAW

Fakultas Hukum Universitas Majalengka

Volume 3 Nomor 1 April 2021

(3) Jalur perpindahan tugas orang tua/wali sebagaimana dimaksud dalam Pasal 12 ayat (2) huruf c paling banyak 5\% (lima persen) dari daya tampung sekolah.

(4) Dalam hal masih terdapat sisa kuota dari jalur pendaftaran sebagaimana dimaksud pada ayat (1) sampai dengan ayat (3), Pemerintah Daerah dapat membuka jalur prestasi sebagaimana dimaksud dalam Pasal 12 ayat (2) huruf d.

Kebijakan zonasi ini, pada kenyataannya berbeda dengan harapan masyarakat pada umumnya. Hal ini karena masyarakat menginginkan sekolah berkualitas bagi anak-anaknya. Seperti dalam memilih sekolah hal pertama yang paling menentukan ialah kualitas sekolah dan lokasi menjadi pertimbangan yang terakhir. Selanjutnya, sekolah yang berkualitas oleh masyarakat biasa dilabeli sebagai sekolah favorit. Faktor utama dalam memilih sekolah ialah tingkat kefavoritan sekolah. Faktor tersebut bahkan mengalahkan faktor lain seperti fasilitas dan guru. Fakta tersebut menunjukkan adanya perbedaan antara masyarakat dan pemerintah melalui kebijakan sistem zonasi dalam hal pemilihan sekolah. Bukan hanya masyarakat, namun sekolah juga tidak bisa memilih siswa yang diinginkan.

Dampak dari dikeluarkannya Permendikbud No. 1 Tahun 2021 tersebut menyebabkan terjadinya kontroversi yang sampai saat ini masih sering dikeluhkan oleh orangtua peserta didik yang akan mencari sekolah selepas tamat dalam jenjang pendidikan, namun pada dasarnya dikeluarkannya Permendikbud No. 1 Tahun 2021 tersebut dimaksudkan sebagai suatu proses pemerataan peserta didik antara pendidikan atau sekolah di wilayah kota dengan pendidikan atau sekolah di wilayah pedesaan dan dari sisi pembuatan kebijakan nya pun, terdapat suatu tujuan baik yaitu agar anak dapat sekolah dekat dengan tempat tinggal tanpa melihat hasil dari Ujian Akhir Nasional (UAN) sebagai syarat mutlak kelulusan dan mencari sekolah. Penerapan sistem zonasi juga memiliki tujuan untuk menghapus istilah sekolah favorit pada Sekolah Negeri yang memang paling diminati di seluruh wilayah di Indonesia. Hal tersebut didasarkan karena terdapat pandangan dualisme dalam sistem pendidikan terkait sekolah favorit dan sekolah non favorit. Selain itu juga penerapan sistem zonasi terhadap PPDB didasarkan oleh keinginan pemerintah untuk memberikan pendidikan yang baik dan mumpuni bagi seluruh warga negaranya.

Akan tetapi konsekuensi dari pemberlakuan kebijakan tersebut, timbulnya suatu permasalahan akibat ditetapkannya sistem zonasi tersebut. Hal ini dikarenakan sistem penerapan terkait zonasi sekolah diserahkan ke masingmasing pemerintah daerah, dengan tidak mencermati terlebih dahulu, terkait faktor-faktor seperti pendataan penduduk, jarak sekolah dan akses sekolah dari masing-masing daerah. Selain itu juga sistem zonasi tersebut kurang dilakukannya sosialisasi sehingga menimbulkan permasalahan, terlebih lagi terkait dikeluarkannya Permendikbud No. 1 Tahun 2021 yang sampai saat ini masih menjadi polemik bagi orang tua peserta didik baru yang akan mencari sekolah. Beranjak dari permasalahan tersebut, dikhwatirkan akan berdampak 
PRESUMPTION of LAW

Fakultas Hukum Universitas Majalengka

Volume 3 Nomor 1 April 2021

kurang baik dalam teknis pelaksanaanya di lapangan dan berdasarkan dari latar belakang tersebut, maka penulis tertarik untuk melakukan penelitian lebih lanjut yang akan dituangkan dalam bentuk penelitian dengan judul "Tinjauan Yuridis Penerimaan Peserta Didik Baru Dalam Sistem Zonasi”

\section{B. Identifikasi Masalah}

Berdasarkan latar belakang di atas, maka dapat dirumuskan Identifikasi Masalah sebagai berikut :

1. Bagaimanakah Penerimaan Peserta Didik Baru Dalam Sistem Zonasi

2. Faktor-faktor apa yang menjadi kendala Dalam Penerimaan Peserta Didik Baru

\section{Tujuan Penelitian}

Sesuai dengan permasalahan di atas, maka tujuan penelitian ini adalah:

1. Untuk mengetahui dan menganalisis Penerimaan Peserta Didik Baru Dalam Sistem Zonasi

2. Untuk mengetahui dan menganalisis Faktor yang menjadi kendala Dalam Penerimaan Peserta Didik Baru

\section{Kerangka Pemikiran}

Kerangka pemikiran merupakan model konseptual tentang hubungan antara teori dengan berbagai faktor yang diidentifikasi sebagai masalah yang penting. Emory Cooper memberikan pendapat mengenai pengertian teori bahwa "Teori adalah suatu kumpulan konsep, definisi, proposisi, dan variabel yang berkaitan satu sama lain secara sistematis dan telah digeneralisasi sehingga dapat menjelaskan dan memprediksi suatu fenomena (fakta-fakta) tertentu". Dengan demikian teori merupakan sumber tenaga bagi penelitian, dimana seiring perkembangan zaman, teori dikembangkan dan dimodifikasi oleh berbagai penelitian kemudian daripada itu teori menyediakan serangkaian konsep penjelas (explanatory concepts) sehingga tanpa sebuah teori, tidak akan terlaksana penelitian. Penelitian ini menggunakan kerangka teori salah satunya mengenai Hak Asasi Manusia.

Hak Asasi Manusia (HAM) merupakan isu global yang penegakannya telah menjadi komitmen dunia internasional. Indonesia sebagai bagian dari tatanan dunia internasional telah meratifikasi sebagian besar komponenkomponen HAM. Konskuensinya dari hal tersebut di atas adalah adanya keharusan untuk menegakkan dan mematuhi hal-hal yang berhubungan dengan HAM, pembukaan Pernyataan Umum tentang Hak-Hak Asasi Manusia (Universal Declaration of Human Rights; singkatan: UDHR) mengamanatkan bahwa nila-inilai hak asasi manusia harus disosialkan melalui pendidikan dan pengajaran yang sistematis dan terprogram, sebab pemahaman dan pengetahuan tentang hak asasi manusia merupakan suatu hal yang bersifat individual dan butuh adanya pemahaman. Oleh karena itu, agar hak asasi manusia menjadi suatu nilai yang dapat dipahami oleh setiap orang diperlukan 
PRESUMPTION of LAW

Fakultas Hukum Universitas Majalengka

Volume 3 Nomor 1 April 2021

adanya proses internalisasi yang sistematis dan terprogram melalui berbagai kegiatan pendidikan dan pengajaran. ${ }^{5}$

Rasa tanggung jawab terhadap internalisasi nilai-nilai hak asasi manusia bisa dijadikan sebagai prioritas dalam penyelenggaraan pendidikan di sekolah. Adapun dorongan utama untuk menekankan perlunya nilai-nilai HAM dalam pelaksanaan pendidikan di lingkungan sekolah antara lain adalah karena diperlukannya perubahan sistem-sistem nilai dalam kehidupan masyarakat dewasa ini. Menurut UNESCO untuk memperkuat pembentukan nilai dan kemampuan seperti solidaritas,kreativitas, tanggungjawab, toleransi dan sebagainya, perlu adanya internalisasi nilai nilai hak asasi manusia dalam setiap kurikulum yang digunakan oleh setiap jenjang pendidikan.

Dengan demikian maka nilai-nilai HAM harus mendapat tempat penting dalam penyelenggaraan pendidikan di sekolah. Output pendidikan haruslah manusia yang mempunyai kepribadian yang toleran, inklusif, demokratis terhadap berbagai pengelompokan masyarakat berdasarkan paham suku bahasa maupun agama. Hal ini penting untuk diperhatikan karena salah satu tugas pendidikan adalah membentuk pribadi manusia yang beradab dan berbudaya, yang dapat menghormati adanya perbedaandan keragaman. Di tengah-tengah maraknya paham globalisasi yang bergulir secara paradoks menimbulkan berbagai kesadaran dan budaya baru di tengah tengah masyarakat, oleh karena itu untuk menghadapi perubahan tersebut diperlukan pendidikan pluralitas, HAM, dan demokrasi yang dapat merespon lahirnya manusia yang beradab dan berbudaya.

Pendidikan mempunyai peranan penting dalam berbagai aspek kehidupan manusia. Azyumardi menegaskan bahwa pendidikan merupakan salah satu agen perubahan sosial pendidikan di satu sisi dipandang sebagai suatu variabel modernisasi yang mengantarkanmasyarakat mencapai suatu kemajuan. ${ }^{6}$

Pendidikan dengan demikian menjadi variabel yang tidak dapat diabaikan dalam transformasi pengetahuan nilai-nilai dan keterampilan yang dilakukan secara sistematis dan berkesinambungan. Dalam kontekini, pendidikan memiliki dua fungsi utama yaitu fungsi konservatif dan progresif. Oleh sebab itu, kebudayaan dan keyakinan umat manusia terus menerus berusaha menjaga dan mempertahankan penyelenggaraan pendidikan secara turun temurun. Penyelenggaraan pendidikan selanjutnya menjadi kewajiban kemanusiaan atau sebagai strategi budaya dalam rangka mempertahankan kehidupan mereka. Begitu pentingnya arti pendidikan bagi umat manusia menyebabkan banyak peradaban manusia yang mengharuskan masyarakat untuk tetap menjaga eksistensi dan keberlangsungan pendidikan. Pada akhirnya manusia secara tegas menetapkan bahwa pendidikan merupakan salah satu hak asasi manusia, salah satu hak dasar yang seharusnya dimiliki oleh setiap orang, baik sebagai warga suatu negara maupun sebagai warga dunia. Pemerintah berkewajiban untuk menyelenggarakan pendidikan apapun kondisi yang

5 Abdul Khakim, Hak Asasi Manusia Dalam Perspektif Pendidikan Islam, Jurnal Evaluasi Pasuruan, Vol.2, No. 1, Maret 2018, hlm 378

${ }^{6}$ Azyumardi Azra, Pembaharuan Pendidikan Islam, dalam Marwan Saridjo, Bunga Rampai Pendidikan Agama Islam, Amisco, Jakarta. 1996, hlm. 2-3 
PRESUMPTION of LAW

Fakultas Hukum Universitas Majalengka

Volume 3 Nomor 1 April 2021

melingkupinya. Tidak ada alasan bagi setiap warga negara untuk tidak mendapat hak-hak dasar tersebut. Tugas negara dalam urusan HAM adalah melindungi, mempromosikan dan mencegah pelanggaran terhadap hak asasi manusia bagi warganya. Dengan demikian wajib belajar dalam konteks HAM adalah kewajiban negara untuk menyediakannya.

Pendidikan merupakan hak asasi manusia yang harus dimiliki oleh setiap warga negara, pendidikan memikul berat tanggungjawab untuk mewujudkan pelaksanaan hak asasi manusia tersebut, seperti kebebasan mengeluarkan pendapat, kebebasan berekspresi, kebebasan untuk mengakses informasi secara benar dan jujur, kebebasan memilih tempat pendidikan, kebebasan berserikat dan lain sebagainya. Jadi dalam hak memperoleh pendidikan terdapat kewajiban yang harus dilaksanakan, yakni kewajiban untuk menyelenggarakan pendidikan yang berkeadilan dan berkeadaban.Tanpa dilandasi adanya kesadaran untuk mewujudkan kewajiban tersebut maka pendidikan yang berorientasi pada HAM sulit untuk direalisasikan. Dalam hal ini Lembaga pendidikan harus merespon persoalan HAM. Sekolah sebagai lembaga pendidikan hendaknya dapat menjadi tempat khusus untuk tumbuh dan berkembang. Peserta didik diberi kesempatan untuk berkembang, mengembangkan minat dan kemampuannya. Perkembangan memerlukan penghayatan kebebasan sebagai bagian dari asas demokrasi yang realisasinya adalah adanya kebebasan untuk berfikir dan berpendapat, sekaligus kebebasan untuk memilih sekolah atau tempat pendidikan sesuai dengan keinginannya.

PPDB berdasar zonasi adalah sebuah sistem yang mengganggu hakekat pendidikan itu sendiri. Sistem zonasi akan sangat berpengaruh pada psikologis peserta didik dalam pengembangan semua potensi yang ada dalam dirinya. Akan ada banyak sekali peserta didik yang masuk ke sekolah tertentu bukan murni karena keinginanya sendiri tetapi karena terpaksa atau dipaksa oleh wilayah atau zona yang telah daitur oleh pemerintah. Selain itu juga akan ada sekian banyak calon peserta didik jika dilihat dari kemampuan akademik dan prestasinya sangat layak masuk disekolah sesuai pilihan dan sesuai kecocokan psikologis mereka gagal gara gara jarak tempuh tidak berada di zona pendidikan yang diinginkan. Sangat miris dan memprihatinkan jika pemrintah masih sibuk mengurus dan mengatur seseorang yang ingin mengembangkan potensi dan ketrampilan disatuan pendidikan tertentu di batasi oleh wilayah atau zona. Dengan demikian, PPDB berdasar zonasi selain melanggar hakekat dari pendidikan juga dapat dikatakan melanggar Hak Asasi manusia khususnya hak asasi untuk mengembangkan diri (aktualisasi diri). Kalau yang diharapkan pemerintah adalah pemerataan mutu pendidikan mestinya tidak harus dilakukan dengan PPDB berdasar zonasi tetapi dilakukan dengan cara perubahan pengelolaan atau manajemen pendidikan yang ideal, penyediaan tenaga pendidik dan kependidikan yang memadai, peningkatan profesionalisme guru secara optimal, penyediaan fasilitas atau sarana pendidikan dan pembelajaran yang cukup. Kalaupun hanya melalui sistem zonasi perataan pendidikan dapat dilakukan, maka angka $90 \%$ dinilai belum menjawab kebutuhan yang dimaksud. 
PRESUMPTION of LAW

Fakultas Hukum Universitas Majalengka

Volume 3 Nomor 1 April 2021

Hal ini dibuktikan melalui banyak demonstrasi yang dilakukan oleh berbagai kalangan terkait dengan pemberlakuan sistem zonasi PPDB ini. Oleh karena itu Dinamika Sistem pendidikan Indonesia saat ini kembali hangat diperbincangkan pasca pemberlakuan sistem Zonasi sebagaimana yang diatur dalam Peraturan Menteri Pendidikan Dan Kebudayaan Nomor 1 Tahun 2021 tentang Penerimaan Peserta Didik Baru Pada Taman Kanak-Kanak, Sekolah Dasar, Sekolah Menengah Pertama, Sekolah Menengah Atas, Dan Sekolah Menengah Kejuruan

\section{E. Metode Penelitian}

Mengacu pada judul dan masalahnya, penulisan jurnal ini termasuk jenis penelitian normatif, yaitu penelitian yang difokuskan untuk mengkaji penerapan kaedah-kaedah atau norma-norma hukum positif. ${ }^{7}$ Tipe ini dipergunakan, mengingat bahwa obyek penelitian ini adalah pengaturan dan implikasinya bagi Calon Peserta Didik mengenai pengaturan sistem zonasi dalam PPDB Berdasarkan Peraturan Menteri Pendidikan Dan Kebudayaan Nomor 44 Tahun 2019 tentang Penerimaan Peserta Didik Baru Pada Taman Kanak-Kanak, Sekolah Dasar, Sekolah Menengah Pertama, Sekolah Menengah Atas, Dan Sekolah Menengah Kejuruan.

Metode pendekatan yang digunakan yang digunakan dalam penelitian adalah pendekatan perundang-undangan digunakan untuk meneliti aturan terkait pengaturan dan implikasinya bagi Calon Peserta Didik mengenai pengaturan sistem zonasi dalam PPDB Berdasarkan Permendikbud RI Nomor 1 Tahun 2021; pendekatan konsep digunakan untuk memahami mengenai konsep-konsep sistem zonasi; dan pendekatan analitis digunakan untuk mengetahui makna yang dikandung oleh istilah-istilah yang digunakan dalam peraturan perundang-undangan secara konsepsional, sekaligus mengetahui penerapannya dalam praktik-praktik, yang dilakukan dengan dua cara yaitu berusaha memperoleh makna baru dan menguji istilah-istilah hukum dalam praktik melalui analisis Permendikbud RI Nomor 1 Tahun 2021.

Spesifikasi penelitian Spesifikasi penelitian yang akan dipergunakan adalah diskriptif analitis, yaitu menggambarkan peraturan perundang-undangan yang berlaku sebagai hukum positif dikaitkan dengan teori hukum dan praktek pelaksanaan hukum positif dalam masyarakat. ${ }^{8}$ Dengan demikian, untuk mendapatkan gambaran yang jelas mengenai mengenai pengaturan dan implikasi tentang sistem zonasi dalam PPDB Berdasarkan Permendikbud RI Nomor 1 Tahun 2021, maka dalam penelitian ini akan diuraikan hasil-hasil penelitian sesuai dengan permasalahan dan tujuan yang akan dicapai serta menganalisisnya dari segi peraturan yang berlaku terkait dengan sistem pendidikan

7 Ibrahim, Johnny. Teori dan metodologi penelitian hukum normatif. Bayumedia Publishing, Malang,2006, hlm 57

${ }^{8}$ Bambang Sunggono, Metode Penelitian Hukum PT. Raja Grafindo Persada, Jakarta, 2002, hlm 36 . 
PRESUMPTION of LAW

Fakultas Hukum Universitas Majalengka

Volume 3 Nomor 1 April 2021

Metode pengumpulan data berdasarkan tipe penelitian yang dipergunakan dalam penelitian ini adalah yuridis normatif, maka untuk mendapatkan data yang objektif, jenis data yang dibutuhkan adalah data sekunder. Data ini diambil dengan cara penelitian kepustakaan, yaitu mempelajari literatur-literatur untuk memperoleh data sekunder, yang terdiri dari bahan hukum primer, bahan hukum sekunder dan bahan hukum tertier. Bahan hukum primer adalah bahan hukum yang bersifat autoritatif (mempunyai otoritas), dan bahan-bahan hukum yang mengikat, yakni norma (dasar) atau kaidah dasar dan peraturan-peraturan dasar, seperti UndangUndang Dasar 1945, serta peraturan perundang-undangan yang berkaitan penerimaan peserta didik baru, seperti UUD 1945, KUHP, Undang - Undang Nomor 20 tahun 2003 tentang Sistem Pendidikan Nasional Dan Peraturan Menteri Pendidikan Dan Kebudayaan 1 Tahun 2021 tentang Penerimaan Peserta Didik Baru Pada Taman Kanak-Kanak, Sekolah Dasar, Sekolah Menengah Pertama, Sekolah Menengah Atas, Dan Sekolah Menengah Kejuruan. Bahan hukum sekunder adalah bahan hukum yang memberikan penjelasan mengenai bahan hukum primer, berupa hasil-hasil penelitian, karangan ilmiah dari kalangan hukum, dan penelitian-penelitian lain yang relevan dengan penelitian ini. Kemudian bahan hukum tertier adalah bahan yang memberikan petunjuk ataupun penjelasan terhadap bahan hukum primer dan bahan hukum sekunder, berupa kamus, ensiklopedia, majalah, surat kabar dan sebagainya yang dipergunakan untuk melengkapi ataupun menunjang data penelitian ini. Disamping penelitian kepustakaan, penelitian ini juga menggunakan studi Lapangan, yaitu dilakukan dalam rangka memperoleh data primer yang menunjang data sekunder, sehingga dari data primer akan dapat diketahui bagaimana Penerimaan Peserta Didik Baru ( PPDB) dengan memakai sistem zonasi (wilayah).

Setelah data sekunder dan primer terkumpul, kemudian diadakan analisis secara kualitatif yaitu menganalisis data berupa uraian-uraian yang sistematis tanpa mempergunakan bagan-bagan dan rumus statistik

\section{F. Hasil Penelitian dan Pembahasan}

\section{a. Penerimaan Peserta Didik Baru Dalam Sistem Zonasi}

Sejalan dengan berkembangnya zaman, kehidupan masyarakat semakin mengalami kemajuan sehingga peran pendidikan menjadi sangat penting. Pendidikan adalah salah satu faktor utama dalam membangun sumber daya manusia dengan cara memotivasi dan mendorong manusia untuk belajar. Pendidikan merupakan bagian dari kehidupan masyarakat dan juga sebagai penunjang kehidupan masyarakat itu sendiri. ${ }^{9}$

Pendidikan juga sebagai investasi jangka panjang yang mempunyai nilai strategis, baik bagi kepentingan individu maupun kepentingan kelompok.

${ }^{9}$ Hendrawansyah dan Zamroni, Evaluasi Kebijakan Sistem Zonasi Dalam Penerimaan Siswa Baru Sekolah Menengah Atas, Jurnal Kependidikan, Volume 4, Nomor 1, 2020, hlm 71 
PRESUMPTION of LAW

Fakultas Hukum Universitas Majalengka

Volume 3 Nomor 1 April 2021

Setiap manusia dapat mengembangkan potensi dirinya melalui pendidikan yang baik. Oleh sebab itu, pendidikan menjadi perlu untuk ditingkatkan secara terus menerus terutama kualitasnya demi mempersiapkan generasi penerus bangsa yang akan menjadi agen perubahan sehingga memiliki keunggulan yang kompetitif dalam tatanan kehidupan nasional maupun global.

Kualitas pendidikan menjadi tujuan utama yang harus diperjuangkan oleh seluruh elemen pendidikan sehingga dapat menghasilkan sumber daya manusia yang kreatif dalam menghadapi tantangan zaman. Terwujudnya kualitas pendidikan yang baik, sedikit tidaknya juga dipengaruhi oleh lembaga pendidikan. Lembaga pendidikan adalah suatu sarana untuk melayani konsumen berupa siswa, dan masyarakat dari berbagai bidang baik layanan dalam bentuk fisik bangunan maupun layanan berupa fasilitas yang memadai, guru yang bermutu dan profesional.

Salah satu fungsi dari pendidikan adalah menciptakan pengetahuan yang pada akhirnya diakumulasi oleh kelompok masyarakat dan digunakan untuk mengontrol berbagai aspek kehidupan masyarakat. Oleh karena itu, jasa pendidikan sangat dibutuhkan dalam memberikan pelayanan sehingga dapat menciptakan peserta didik yang lebih baik. Alvarez dan Ruiz-Casares menjelaskan bahwa penguatan nilai-nilai sosial yang baik dengan memberikan pelayanan pendidikan yang baik akan membentuk mekanisme pendidikan yang baik serta dapat menjamin pendidikan yang berkelanjutan dari pendidikan itu ${ }^{10}$.

Salah satu strategi pembangunan pendidikan nasional adalah memperluas akses pendidikan yang berkualitas. Pendidikan yang berkualitas akan diperoleh pada sekolah yang berkualitas dan sekolah yang berkualitas akan menghasilkan peserta didik yang berkualitas pula. Pada hakikatnya pendidikan dipercaya sebagai roda penggerak mobilitas sosial yang menjadi tolak ukur bahwa peserta didik mengalami kemajuan dan kesejahteraan. Sebagaimana yang diungkapkan oleh Wu bahwa pendidikan merupakan roda penggerak untuk membangun mobilitas sosial. Sebagian besar manusia berusaha memperbaiki hidupnya melalui pendidikan.

Keberadaan pendidikan dapat memberikan peluang adanya peningkatan status sosial dalam meningkatkan kualitas taraf hidupnya. Terdapat hubungan yang kuat antara tingkat pendidikan dan kehidupan sosial masyarakat. Jika tingkat pendidikannya maju maka tingkat kehidupan sosialnya akan maju begitupun sebaliknya. Dalam hal ini, pendidikan menjadi penting untuk masa depan dan mengatasi persoalan ketidakadilan dalam pendidikan

Dewasa ini terdapat fenomena sekolah favorit yang menjadi tujuan. Fenomena ini muncul karena ada kebijakan untuk memasuki sekolah berdasarkan hasil nilai Ujian Nasional atau nilai ujian sekolah jenjang sekolah di bawahnya. Akibatnya, siswa yang memiliki prestasi tinggi berkumpul pada sekolah favorit. Fenomena sekolah favorit menjadikan

${ }^{10}$ Ibid, hlm 80 
PRESUMPTION of LAW

Fakultas Hukum Universitas Majalengka

Volume 3 Nomor 1 April 2021

ketimpangan prestasi diantara para siswa semakin tajam. Sekolah yang berkualitas semakin berkualitas sebaliknya sekolah yang tidak berkualitas cenderung statis.

Fenomena di atas menyentuh keadilan dalam pelayanan pendidikan. Meskipun latar belakang sosial peserta didik berbeda-beda, namun mereka tetap menginginkan agar mendapatkan kedudukan dan kesempatan yang sama di dalam pendidikan. Mendapatkan pendidikan sama berarti mendapatkan pendidikan yang merata. Semua masyarakat berhak mendapatkannya tanpa membeda-bedakan status sosialnya.

Pada kenyataannya realitas pendidikan di Indonesia belum terdefinisi secara merata. Sekolah yang baik didominasi oleh orang-orang kaya sedangkan orang miskin hanya berkesempatan memasuki sekolah yang mutunya kurang bagus. Oleh karena itu, sekolah yang bermutu akan semakin maju sedangkan sekolah yang tidak bermutu tidak dapat maju dan berkembang. Maka muncullah sekolah favorit dan tidak favorit. Sekolah favorit biasanya dimasuki oleh orang oleh orang-orang kaya sementara sekolah yang tidak favorit biasanya dimasuki oleh orang-orang miskin. Fenomena di atas merupakan penyebab awal terjadinya stratifikasi sosial. Padahal pendidikan diharapkan dapat menghadirkan tatanan sosial yang baik dan bukan sebagai alat untuk menciptakan stratifi kasi sosial. Dengan demikian, kesenjangan kemiskinan antar generasi tetap berjalan. Hal tersebut merupakan ketidaksetaraan yang akan melahirkan ketimpangan di dalam pendidikan .

Pendidikan sebagai sarana mobilitas hanya bisa dimasuki oleh orangorang kaya. Oleh karena itu, pemerintah melalui kebijakan sistem zonasi memutuskan pemerataan pendidikan yang berkualitas. Selain itu pemerintah berupaya untuk menghilangkan ketimpangan yang terjadi di masyarakat mengenai sekolah favorit dan tidak favorit. Perdana mengungkapkan bahwa "penerimaan peserta didik baru dengan sistem zonasi dapat memeratakan pendidikan baik dari sisi input, penyebaran, dan dapat menghilangkan pembelan sekolah favorit dan tidak favorit"11.

Sistem zonasi merupakan jalur yang disediakan bagi peserta didik yang berada di dalam satu lokasi yang dekat dengan sekolah selama minimal satu tahun dengan dibuktikan KTP atau kartu keluarga dan siswa tidak perlu lagi melalui ujian masuk. Adapun tujuan sistem zonasi sekolah adalah: Memeratakan Akses Pendidikan, Mendekatkan Lingkungan Sekolah dengan Lingkungan Keluarga, Menghapuskan Eksklusivitas dan Diskriminasi, Membantu Analisis Perhitungan Kebutuhan Guru dan Distribusinya, Mendorong Kreativitas Guru, Membantu Pemerintah Daerah dalam Memberikan Bantuan.

Jalur sistem zonasi merupakan jalur penerimaan siswa berdasarkan zona tempat tinggal. Kementerian Pendidikan dan Kebudayaan (Kemendikbud), Nomor 1 Tahun 2021 memberlakukan jalur penerimaan ini. PPDB tahun 2021 dapat diikuti calon siswa yang akan masuk TK, SD, SMP, serta

${ }^{11}$ Ibid, 
PRESUMPTION of LAW

Fakultas Hukum Universitas Majalengka

Volume 3 Nomor 1 April 2021

SMA/SMK. Penggunaan sistem zonasi untuk penerimaan siswa baru merupakan salah satu jalur untuk bisa diterima di sekolah. Penerapan sistem zonasi sebenarnya menyasar siswa baru agar mendaftar sekolah sesuai tempat tinggal.

Aturan sistem zonasi PPDB tercantum pada Permendikbud No. 1 Tahun 2021. Harapannya, sekolah favorit dan non-favorit tidak memiliki sekat. Tahun 2020, kuota yang diberikan untuk jalur zonasi PPDB minimal $50 \%$ di setiap sekolah. Sistem zonasi yang diberlakukan pada tahun pembelajaran 2020/2021 memiliki sejumlah perbedaan dengan sistem zonasi PPDB tahun pembelajaran 2019. Perbedaan tersebut mencakup jumlah kuota dari jalur zonasi. Pada tahun 2019, kuota siswa untuk jalur zonasi sebesar $80 \%$ dari $100 \%$. Tahun 2020, kuota jalur zonasi berkurang menjadi $50 \%$ setiap sekolah. Berkurangnya kuota untuk jalur zonasi PPDB tahun pembelajaran 2020/2021 dipengaruhi pemerataan wilayah yang belum bisa mengikuti PPDB online. Selain jalur zonasi, ada beberapa jalur lain yang dapat ditempuh siswa, seperti:

a. PPDB Jalur Afirmasi

Persentase siswa yang berpeluang mendaftar PPDB jalur afirmasi paling sedikit $15 \%$. Pemberlakuan syarat PPDB untuk siswa afirmasi adalah sebagai berikut: PPDB jalur afirmasi ditujukan bagi siswa dari kalangan ekonomi tidak mampu. Menunjukkan bukti berupa surat keikutsertaan dalam program pemerintah terkait penanganan keluarga tidak mampu.Calon siswa memiliki domisili di dalam atau di wilayah zonasi sekolah tujuan. Apabila terbukti melakukan pemalsuan akan diproses secara hukum.

b. PPDB Jalur Perpindahan Tugas Orang Tua atau Wali

Pada penerimaan siswa baru dari jalur perpindahan, kuota yang diberikan sebanyak $5 \%$. Saat ini, kuota jalur pindahan dibuat lebih ketat. Pemberlakuan kuota ini tercantum pada Pasal 13 ayat (3). Terdapat beberapa ketentuan tambahan yang harus dipenuhi oleh siswa apabila ingin mendaftar dengan jalur perpindahan tugas.

c. PPDB Jalur Prestasi

Penerimaan siswa baru dari jalur prestasi yaitu sisa kuota setelah dikurangi jalur zonasi, afirmasi dan perpindahan tugas orang tua/wali murid. PPDB jalur prestasi belum diperuntukkan bagi calon peserta didik yang akan masuk TK dan SD. Kriteria seleksi PPDB jalur prestasi adalah berdasarkan nilai Ujian Nasional atau nilai ujian sekolah. Penghargaan di bidang akademik dan non-akademik dari berbagai tingkat, serta hasil perlombaan juga diperhitungkan. Pada PPDB jalur prestasi, semua dokumen pendukung seperti piagam atau bukti prestasi akan dikumpulkan. Jangka waktu penerbitan dokumen paling cepat enam bulan, sedangkan paling lambat tiga tahun sejak pendaftaran PPDB.

Pada Penerimaan Peserta Didik Baru (PPDB) tahun pembelajaran 2020/2021 tetap memperhatikan protokol kesehatan dimana setiap kepala 
PRESUMPTION of LAW

Fakultas Hukum Universitas Majalengka

Volume 3 Nomor 1 April 2021

dinas pendidikan dan sekolah tidak mengumpulkan siswa dan orang tua secara fisik di sekolah untuk mencegah penyebaran Covid-19. ${ }^{12}$

Diberlakukannya sistem zonasi merupakan ikhtiar dalam mewujudkan Indonesia yang merata dalam bidang pendidikan. Tentu setiap kebijakan memiliki kelebihan dan kekurangannya tersendiri, terlebih pada kebijakan zonasi atau rayonisasi yang masih menjadi kebijakan baru, tentu masih perlu untuk diperbaiki.

Permendikbud Nomor 1 Tahun 2021 sendiri sebenarnya mengandung ketidakadilan. Dalam Pasal 31 ayat (1) dan ayat (2) diatur bahwa untuk jenjang SMP dan SMA calon peserta didik baru kelas 7 (tujuh) SMP dan kelas 10 (sepuluh) SMA dilakukan dengan memprioritaskan jarak tempat tinggal terdekat ke sekolah dalam wilayah zonasi yang ditetapkan. Namun jika jarak tempat tinggal calon peserta didik dengan sekolah sama, maka seleksi pemenuhan kuota atau daya tampung terakhir menggunakan usia peserta didik yang lebih tua. Usia menjadi kritera kedua setelah jarak rumah. Khusus untuk jenjang SMA kriteria usia (setelah jarak rumah) agaknya bermasalah. Jenjang yang diatur dengan faktor usia, yaitu SMP dan SMA.

Khusus untuk PPDB SMP tidak ada masalah dengan kriteria usia (setelah faktor jarak rumah). Karena jika dicermati, Undang-Undang Republik Indonesia Nomor 20 Tahun 2003 tentang Sistem Pendidikan Nasional (UUSPN) Pasal 6 mengatur tentang usia yaitu : "Setiap warga negara yang berusia 7 (tujuh) sampai dengan 15 (lima belas) tahun wajib mengikuti pendidikan dasar". Artinya khusus untuk SD dan SMP ada ketentuan wajib belajar. Oleh karena pendidikan dasar (SD dan SMP) sifatnya wajib, dan ada batasan usia yang secara tegas diatur dalam Undang-Undang Republik Indonesia Nomor 20 Tahun 2003 tentang Sistem Pendidikan Nasional (UUSPN), maka faktor usia logis menjadi faktor penentu kedua dalam seleksi jalur zonasi khusus pendidikan dasar (SD dan SMP). Jika tidak dimasukkan, maka Pemerintah dapat dipersalahkan mengabaikan mereka yang secara hukum lebih patut didahulukan daripada yang tidak.

Jika ketentuan usia dibatasi dengan ketentuan lain (selain jarak), semisal prestasi, maka siswa yang memiliki prestasi lebih (walau usianya lebih muda) kemudian menghilangkan hak mereka yang diwajibkan belajar oleh Undang-undang maka Pemerintah berpotensi melanggar UUD Pasal 31 ayat (2) dan kewajiban memfasilitasi warga negara (pada usia tertentu) untuk melaksanakan kewajibannya. Dalam perspektif ini, khusus untuk jenjang pendidikan dasar (SD dan SMP) aspek usia memang harus lebih diutamakan daripada kecerdasan, dan hal ini sudah sejalan dengan Undang-Undang Republik Indonesia Nomor 20 Tahun 2003 tentang Sistem Pendidikan Nasional (UUSPN).

Berbeda dengan jenjang SMP, tahap pendidikan SMA/SMK secara hukum bukanlah sebuah kewajiban. Undang-Undang Republik Indonesia

12 alf, Mekanisme Aturan PPDB 2020,https:// edukasi. sindonews.com/ read/ 36103/144/ mekanisme-aturan-ppdb-2020-1589861113?showpage=all\#: :text=Apa\%20Itu\% 20Jalur\%20 Zonasi\&text=Jalur\%20sistem\%20zonasi\%20merupakan\%20jalur,SMP\%2C\%20 serta\%20 SMA\%2FSMK. Diakses pada tanggal 21/01/2020 
PRESUMPTION of LAW

Fakultas Hukum Universitas Majalengka

Volume 3 Nomor 1 April 2021

Nomor 20 Tahun 2003 tentang Sistem Pendidikan Nasional (UUSPN) tegas mewajibkan pendidikan dasar 9 tahun bukan 12 tahun. Adapun jenjang SMA/SMK adalah hak warga negara. Artinya, semua warga negara pada dasarnya berhak memasuki jenjang SMA/SMK,bukan merupakan kewajiban. Oleh karena sifatnya adalah hak, maka tugas pemerintah bagaimana mendistribusikan pemenuhan hak tersebut secara fair (adil). Adil artinya tidak boleh ada diskriminasi dalam PPDB zonasi SMA. Tidak dibenarkan ada perlakuan berbeda oleh karena sesuatu kondisi yang seseorang tidak dapat memilihnya (distribusi natural dalam teori keadilan John Rawls). Kriteria semisal Suku, Ras, Agama termasuk Usia misalnya, itu termasuk distribusi natural, "hadiah" dari Tuhan Yang Maha Kuasa, dan bukan pilihan pribadi.

Pada dasarnya pemenuhan hak pada dasarnya harus equal opportunity (ada kesempatan yang setara). Jikapun dibuat kriteria karena sumber daya yang terbatas (daya tampung yang tidak cukup memadai bagi semua), maka kriteria itu pertama-tama tidak boleh dirujuk kepada sesuatu yang tidak dapat diupayakan atau diubah secara harfiah. Dengan demikian, kriteria kedua yang lebih relevan setelah jarak harusnya adalah prestasi siswa. Kriteria prestasi ini akan lebih fair dibandingkan dengan kriteria usia. Kembali pada dasarnya Hak tidak boleh ditentukan atas faktor yang tidak dapat diubah secara lahiriah. Menjadi tua itu pasti, berprestasi adalah pilihan sehingga setiap orang pasti tua namun tidak semua orang bisa berprestasi maka menempatkan usia sebagai variabel dalam seleksi jalur zonasi selain telah melanggar hukum juga melanggar hak mendapatkan pendidikan yang merupakan bagian dari Hak Asasi Manusia dan tidak mencerminkan prinsip keadilan. ${ }^{13}$

\section{Faktor yang menjadi kendala Dalam Penerimaan Peserta Didik Baru}

Penerimaan Peserta Didik Baru (PPDB) dengan sistem zonasi ini telah menyebabkan polemik di masyarakat. Sementara, PPDB dengan sistem zonasi ini dimaksudkan untuk pemerataan kualitas pendidikan. Berikut ini diuraikan kendala PPDB dengan sistem zonasi berdasarkan temuan di lapangan.

a. Sekolah favorit masih terbatas

Sekolah unggulan atau favorit yang diinginkan para orang tua tidak dapat dicapai karena berada di zona yang berbeda. Akibatnya, orang tua terpaksa menyekolahkan anaknya di zona terdekat dengannya yang mutunya kurang baik. Hal tersebut didasarkan pada pengalaman sebelumnya bahwa sekolah-sekolah favorit itu sudah diketahui banyak

${ }^{13}$ M. Armen Lukman, Ketidakadilan Dalam Penerimaan Peserta Didik Baru (PPDB) 2020 dan Langkah Hukum yang Dapat Dilakukan, https://kliklegal.com/ketidakadilan-dalampenerimaan-peserta-didik-baru-ppdb-2020-dan-langkah-hukum-yang-dapat-dilakukan/diakses pada tanggal 21/1/2020 
PRESUMPTION of LAW

Fakultas Hukum Universitas Majalengka

Volume 3 Nomor 1 April 2021

orang karena selalu dibanjiri pendaftar. Artinya, sekolah favorit ini diperebutkan oleh banyak orang tua agar anaknya bisa sekolah di sana. Bahkan, sekolah favorit ini diasumsikannya sebagai sekolah yang dapat memberikan pengalaman yang lebih jika dibandingkan dengan sekolah yang tidak favorit. Dengan sistem zonasi juga memberikan respon positif dari para orang tua yang rumahnya dekat dari sekolah yang difavoritkan oleh banyak orang tua. Sekolah favorit menjadi daya tarik yang luar biasa bagi para orang tua yang ingin mendapatkan sekolah yang baik untuk anak-anaknya. Namun, dengan sistem zonasi ini, para orang tua juga harus siap ditolak ketika banyak anak di sekitar sekolah favorit tersebut mendaftarkan diri di sekolah tersebut.

b. Pemerataan kualitas pendidikan yang masih timpang

Pemerataan kualitas pendidikan yang dimaksudkan adalah pemerataan dalam memberikan akses pendidikan, yakni berupa sarana prasarana dan fasilitas sekolah, metode pembelajaran, kualitas dan distribusi guru. Ukuran pemerataan kualitas pendidikan yang dimaksud tersebut mencakup semua sekolah. Dengan kata lain, semua sekolah memiliki sarana prasarana dan fasilitas sekolah yang sama, kualitas dan distribusi guru yang sama juga. Namun, fakta temuan di lapangan berbeda. Bahkan, masyarakat sendiri mampu membedakan antara satu sekolah dengan sekolah yang lainnya ditinjau dari pemerataan kualitas pendidikan di atas. Hal tersebut telah memicu polemik di masyarakat. Masyarakat masih menganggap bahwa pemerataan kualitas pendidikan belum merata atau masih timpang. Alhasil, PPDB dengan sistem zonasi belum dapat diterima. Pemerintah dinilai tidak adil karena masih terdapat ketimpangan sekolah yang satu dengan yang lain dilihat dari fasilitas dan kualitas guru. terciptanya pemerataan kualitas pendidikan yang dimaksudkan oleh pemerintah masih jauh dari harapan meskipun dengan PPDB sistem zonasi ini pemerintah akan mewujudkannya. Pemerataan kualitas pendidikan ini, seperti harapan pemerintah tersebut, bisa juga dipetakan melalui PPDB sistem zonasi ini. Dengan kata lain, pemerintah akan mengupayakan secepat mungkin kebutuhan- kebutuhan sekolah seperti sekolah-sekolah yang banyak diminati oleh masyarakat. Sekolahsekolah yang diminati oleh masyarakat tersebut bukan tidak beralasan. Alasan utamanya, bisa jadi karena sekolah tersebut didukung oleh fasilitas dan kualitas guru yang ideal. Oleh karena itu, PPDB dengan sistem zonasi ini akan berjalan baik untuk beberapa tahun ke depan jika pemerataan kualitas pendidikan diwujudkan pada semua sekolah. Kepala sekolah dan guru juga mengakui bahwa pemerataan kualitas pendidikan yang diharapkan oleh pemerintah dapat terwujud secepat mungkin dengan memenuhi kebutuhan sekolah. Secara pribadi, kepala sekolah juga masih melihat ketimpangan di beberapa sekolah. Padahal, status sekolahnya sama, yaitu sekolah negeri. Untuk mewujudkan semua itu, dibutuhkan waktu dan dana yang besar. Dengan begitu, PPDB dengan sistem zonasi, terciptanya pemerataan kualitas pendidikan seperti 
PRESUMPTION of LAW

Fakultas Hukum Universitas Majalengka

Volume 3 Nomor 1 April 2021

harapan pemerintah akan terwujud. Artinya, PPDB dengan sistem zonasi ini tidak menimbulkan polemik lagi di masyarakat.

Dari penjelasan di atas, dapat dipahami bahwa pemerataan kualitas pendidikan seharusnya telah merata sebelum PPDB dengan sistem zonasi ini. Alasan pemerintah dengan tujuan menciptakan pemerataan kualitas pendidikan melalui PPDB dengan sistem zonasi ini mendapatkan perhatian serius dari masyarakat, baik calon wali murid maupun dari para guru. Tidak heran, masyarakat masih menganggap bahwa masih ada sekolah- sekolah yang difavoritkan dan tidak difavoritkan. Masih ada lagi sekolah yang satu ramai dengan pendaftar dan sekolah yang lain malah kurang diminati. Dengan kata lain, masyarakat sudah tahu mana sekolah yang bagus untuk anak-anaknya. Hal inilah yang harus dievaluasi oleh pemerintah sehingga PPDB dengan sistem zonasi ini sesuai dengan harapan pemerintah.

c. Kurangnya sosialisasi dari pemerintah

Aturan PPDB yang dilakukan oleh pemerintah pusat seharusnya melibatkan pemerintah daerah. Pelibatan pemerintah daerah akan membantu pemerintah pusat dalam menyusun aturan yang tepat. Penyusunan aturan yang tepat diharapkan tidak menimbulkan kesalahpahaman di masyarakat. Kondisinya, masyarakat masih menolak kebijakan PPDB sistem zonasi ini. Padahal, masyarakat dan sekolah sebagai sasaran pelaksana aturan tersebut harus mengetahui secara detail aturan dalam PPDB. Dengan begitu, PPDB dengan sistem zonasi perlu dilakukan dan dapat berjalan dengan baik. Namun, PPDB dengan sistem zonasi ini mendapatkan kritikan dari masyarakat.

Masyarakat menilai bahwa pemerintah pusat seharusnya lebih gencar mensosilaisasikan secara teknis jauh hari sebelumnya sehingga maksud dan tujuan pemerintah diketahui dengan baik. Sosialisasi PPDB ini harus dilakukan secara terstruktur, sistematis, dan masif agar masyarakat paham. Padahal, kebijakan sistem zonasi ini dilakukan untuk memberi pelayanan akses yang berkeadilan kepada masyarakat, pemerataan kualitas pada semua satuan pendidikan, dan mendorong masyarakat dalam penyelenggaraan pendidikan. Dengan demikian, tidak ada lagi kecenderungan terpusatnya orang tua mendaftarkan anaknya pada sekolah tertentu yang dianggapnya unggulan dan favorit. Apalagi, membandingkan fasilitas dan kualitas satuan pendidikan yang satu dengan yang lainnya. Dengan kata lain, semua sekolah harus unggul dan berkualitas. Pemerintah juga diminta untuk meningkatkan sarana dan prasarana sekolah antara sekolah yang satu dengan yang lain agar tidak jauh berbeda. Selain itu, distribusi dan kualitas guru juga harus merata.

Pemerintah pusat dan pemerintah daerah harus bersinergi dalam mensosialisasikan PPDB dengan sistem zonasi ini jauh hari sebelumnya. Hal itu dapat dilakukan melalui kegiatan sosialisasi Dinas Pendidikan dengan sekolah-sekolah, melalui rapat komite, pengumumanpengumuman melalui media massa dan elektronik, atau bisa juga melalui pengumuman-pengumuman pengeras suara di masjid dengan 
PRESUMPTION of LAW

Fakultas Hukum Universitas Majalengka

Volume 3 Nomor 1 April 2021

bekerjasama dengan tokoh masyarakat, tokoh agama, dan tokoh pemuda. Dengan begitu, kebijakan PPDB dengan sistem zonasi ini tidak menimbulkan polemik di masyarakat ${ }^{14}$

Berdasarkan pengaturan yang telah ditetapkan dalam Permendikbud RI No 1 Tahun 2021, maka dapat dilakukan analisis yang akan diuraikan berikut ini.

Perlu diketahui sebelumnya bahwa kebijakan sistem zonasi ini lahir sejak tahun 2017 yang lalu melalui Permendikbud RI No 17 Tahun 2017. Kebijakan sistem zonasi ini tampak terjadi bongkar pasang, betapa tidak setahun berikutnya dilakukan revisi melalui Permendikbud RI No 14 Tahun 2018. Selang beberapa bulan kembali direvisi kembali melalui Permendikbud RI No 51 Tahun 2018, setahun berikutnya lagi dilakukan revisi melalui Permendikbud RI No 20 Tahun 2019. Selang beberapa bulan lagi kembali direvisi melalui Permendikbud RI No 44 Tahun 2019, hingga akhirnya dilakukan perubahan melalui Permendikbud RI No 1 Tahun 2021.

Bertitik tolak dari kenyataan tersebut di atas, memang telah terjadi bongkar pasang kebijakan sistem zonasi dalam penerimaan peserta didik baru. Dalam hal ini sesungguhnya terlihat jelas kegagapan pemerintah untuk mengatakan ketidaksiapan pemerintah dalam hal ini adalah Kementrian Pendidikan Kebudayaan, sehingga menyebabkan calon peserta didik dan para orang tua, cemas, dan kebingungan.

Apabila dicermati dengan seksama, pemerintah dengan mengeluarkan kebijakan sistem zonasi ini, sesungguhnya tidak memperhatikan peraturan diatasnya, yaitu Peraturan Pemerintah Nomor 13 Tahun 2015 tentang Perubahan Kedua Atas Peraturan Pemerintah Nomor 19 Tahun 2005 tentang Standar Nasional Pendidikan (selanjutnya akan disingkat dengan Peraturan Pemerintah Nomor 13 Tahun 2015) yang merupakan peraturan pelaksana dari UU Nomor 20 Tahun 2003. Bertitik tolak dari ketentuan-ketentuan yang telah dipaparkan tersebut, maka dapat diketahui bahwa ketentuan tentang sistem penerimaan peserta didik baru dalam Permendikbud RI No 1 Tahun 2021 bertentangan dengan peraturan diatasnya yaitu PP RI No. 13 Tahun 2015 yang merupakan penjabaran dari UU No 20 Tahun 2003 tentang Sistem Pendidikan Nasional

Dalam Permendikbud RI No. 1 Tahun 2021 tepatnya Pasal 31 mengatur bahwa zonasi digunakan sebagai dasar untuk pertimbangan seleksi masuk jenjang pendidikan berikutnya. Artinya bahwa dalam pasal ini menetapkan penentuan calon peserta didik yang dapat lolos seleksi dalam penerimaan peserta didik baru menggunakan dasar pertimbangan zonasi, yang mana calon peserta didik baru akan diterima dengan didasarkan pada prioritas jarak tempat tinggal calon peserta didik yang terdekat dengan Sekolah dan apabila daya tampung terakhir dari sisa kuota jalur zonasi, jika terdapat

${ }^{14}$ Muammar, Problematika Penerimaan Peserta Didik Baru (PPDB) Dengan Sistem Zonasi Di Sekolah Dasar (SD) Kota Mataram, Jurnal PGMI ẽl-Midad. uinmataram. Vol. 11 No.1 Juni 2019 hlm. 58 
PRESUMPTION of LAW

Fakultas Hukum Universitas Majalengka

Volume 3 Nomor 1 April 2021

calon peserta didik yang memiliki jarak tempat tinggal dengan Sekolah sama, maka menggunakan usia peserta didik yang lebih tua berdasarkan surat keterangan lahir atau akta kelahiran

Sedangkan dalam PP Nomor 13 Tahun 2015 tepatnya Pasal 68 huruf b mengatur bahwa hasil ujian nasional yang digunakan sebagai dasar untuk perimbangan seleksi masuk jenjang pendidikan berikutnya. Artinya bahwa penentuan calon peserta didik yang dapat lolos seleksi dalam penerimaan peserta didik baru menggunakan dasar pertimbangan Ujian Nasional semata dan tidak dikenal zonasi ${ }^{15}$

Sehubungan dengan hal tersebut di atas apabila terdapat peraturan perundang-undangan yang tidak sesuai seperti terjadi pada Permendikbud RI No. 1 Tahun 2021 dengan PP RI No. 13 Tahun 2015 yang merupakan penjabaran dari UU RI No. 20 Tahun 2003, maka konsekuensinya harus dicabut, dan apabila tidak dicabut seyogyanya harus dikaji ulang untuk disesuaikan dengan peraturan diatasnya, sehingga tercipta harmonisasi peraturan perundang-undangan. Hal ini selaras dengan ajaran Hans Kelsen. Hans Kelsen mengungkapkan sebuah ajaran (dogma) yaitu Stufenbautheory yang mengungkapkan bahwa:

"Norma hukum itu berjenjang-jenjang dan berlapis-lapis dalam suatu hierarki tata susunan, di mana suatu norma yang lebih rendah berlaku, bersumber dan berdasar pada norma yang lebih tinggi, norma yang lebih tinggi berlaku, bersumber dan berdasar pada norma yang lebih tinggi lagi, demikian seterusnya sampai pada suatu norma yang tidak dapat ditelusuri lebih lanjut dan bersifat hipotesis dan fiktif, yaitu norma dasar (Grundnorm)". ${ }^{16}$

Inspirasi Teori Perjenjangan (Stufenttheory) norma hukum Hans Kelsen diilhami oleh seorang muridnya yang bernama Adolf Merkl yang mengemukakan bahwa suatu norma hukum itu selalu mempunyai dua wajah (das doppeltte rechsantlizst). Menurut Adolf Merkl :

"Suatu norma hukum itu ke atas bersumber dan berdasar pada norma yang diatasnya, tetapi ke bawah ia juga menjadi dasar dan menjadi sumber bagi norma hukum dibawahnya, sehingga suatu norma hukum itu mempunyai masa berlaku (rechtskracht) yang relatif oleh karena masa berlakunya suatu norma hukum itu tergantung pada norma hukum yang berada diatasnya, sehingga apabila norma hukum yang berada diatasnya dicabut atau dihapus, maka norma-norma hukum yang berada dibawahnya tercabut atau terhapus pula". ${ }^{17}$

${ }^{15}$ Tri Mulyani, Dewi Tuti Muryati, Analisis Yuridis Mengenai Sistem Zonasi Dalam Penerimaan Peserta Didik Baru, Jurnal USM Law Review, Universitas Semarang, Vol 3 No 1 Tahun 2020, hlm 50

${ }^{16}$ Ibid. Lihat juga Hans Kelsen, General Theory of Law State Russell \& Russell, New York:,1945, hlm 113

${ }^{17}$ Ibid. 
PRESUMPTION of LAW

Fakultas Hukum Universitas Majalengka

Volume 3 Nomor 1 April 2021

Berdasarkan teori Adolf Merkl tersebut, dalam teori jenjang normanya Hans Kelsen juga mengemukakan bahwa suatu norma hukum itu selalu berdasar dan bersumber pada norma yang diatasnya, tetapi ke bawah norma hukum itu juga menjadi sumber dan menjadi dasar bagi norma lebih rendah daripadanya. Dengan demikian dalam hal susunan/hirarki sistem norma, norma yang tertinggi (norma dasar) itu menjadi tempat bergantungnya norma-norma dibawahnya sehingga apabila norma dasar berubah, maka akan menjadi rusaklah sistem norma yang berada dibawahnya.

Teori Jenjang Norma Stufenbautheory Hans Kelsen dikembangkan ke dalam tatanan kenegaraan (ranah hukum tata negara) oleh muridnya Hans Nawiasky dalam bukunya yang berjudul Allgemeine Rechtslehre mengemukakan bahwa sesuai dengan teori Hans Kelsen:

"Suatu norma hukum dari negara manapun selalu berlapis-lapis dan berjenjang-jenjang di mana norma yang berada di bawah berlaku, berdasar dan bersumber pada norma yang lebih tinggi, norma yang lebih tinggi berlaku, berdasar dan bersumber pada norma yang lebih tinggi lagi, sampai pada suatu norma yang tertinggi yang disebut norma dasar, tetapi Hans Nawiasky juga berpendapat bahwa selain norma itu berlapislapis dan berjenjang, norma hukum dalam suatu negara itu juga berkelompok-kelompok". ${ }^{18}$

Berdasarkan uraian tersebut, maka dapat disimpulkan bahwa Stufenbautheory dari Hans Kelsen diterapkan juga di Negara Indonesia, yang mana di Negara Indonesia diterjemahkan melalui UU RI No. 12 Tahun 2011 tentang Pembentukan Peraturan Perundang-undangan, yang didalamnya diatur tentang tata hierarki peraturan perundang-undangan yang berjenjang-jenjang dan berlapis-lapis dalam suatu hierarki tata susunan peraturan perundang-undangan, dengan konsekuensi suatu norma yang lebih rendah berlaku, bersumber dan berdasar pada norma yang lebih tinggi, norma yang lebih tinggi berlaku, bersumber dan berdasar pada norma yang lebih tinggi lagi, demikian seterusnya sampai pada suatu norma yang tidak dapat ditelusuri lebih lanjut dan bersifat hipotesis dan fiktif, yaitu norma dasar yaitu Pancasila yang menjadi roh UUD NRI Tahun 1945, sehingga oleh karena Permendikbud RI No. 1 Tahun 2021 dengan PP RI No. 13 Tahun 2015 yang merupakan penjabaran dari UU No. 20 Tahun 2003 tentang Sistem Pendidikan Nasional kedudukannya lebih rendah, maka konsekuensinya harus dicabut, dan apabila tidak dicabut seyogyanya harus dikaji ulang untuk disesuaikan dengan peraturan diatasnya, sehingga tercipta harmonisasi peraturan perundang-undangan.

Berdasarkan analisis yang telah dipaparkan tersebut di atas, maka dapat diketahui bahwa pengaturan sistem zonasi dalam PPDB yang diatur berdasarkan Permendikbud RI No 1 Tahun 2021 tepatnya Pasal 31, bertentangan dengan peraturan diatasnya yaitu PP RI No 13 Tahun 2015, tepatnya Pasal 68 huruf $\mathrm{b}$ yang menetapkan bahwa hasil ujian nasional 
PRESUMPTION of LAW

Fakultas Hukum Universitas Majalengka

Volume 3 Nomor 1 April 2021

digunakan sebagai dasar untuk pertimbangan seleksi masuk jenjang pendidikan berikutnya, yang mana peraturan pemerintah ini merupakan penjabaran dari UU RI No 20 Tahun 2003. Sehingga berdasarkan Stufenbautheory dari Hans Kelsen yang diterjemahkan di Indonesia melalui UU RI No. 12 Tahun 2011 maka Permendikbud RI No 20 Tahun 2019 harus dicabut, atau perlu dikaji ulang dan disesuaikan dengan peraturan diatasnya agar tercipta harmonisasi peraturan perundang undangan.

\section{G. Kesimpulan}

1. Diberlakukannya sistem zonasi merupakan ikhtiar dalam mewujudkan Indonesia yang merata dalam bidang pendidikan, namun setiap kebijakan memiliki kelebihan dan kekurangannya tersendiri, terlebih pada kebijakan zonasi atau rayonisasi yang masih menjadi kebijakan baru, tentu masih perlu untuk diperbaiki. Permendikbud Nomor 1 Tahun 2021 sendiri sebenarnya mengandung ketidakadilan. Dalam Pasal 31 ayat (1) dan ayat (2) diatur bahwa untuk jenjang SMP dan SMA calon peserta didik baru kelas 7 (tujuh) SMP dan kelas 10 (sepuluh) SMA dilakukan dengan memprioritaskan jarak tempat tinggal terdekat ke sekolah dalam wilayah zonasi yang ditetapkan, akan tetapi jika jarak tempat tinggal calon peserta didik dengan sekolah sama, maka seleksi pemenuhan kuota atau daya tampung terakhir menggunakan usia peserta didik yang lebih tua. Seharusnya kriteria kedua yang lebih relevan setelah jarak adalah prestasi siswa. Kriteria prestasi ini akan lebih fair dibandingkan dengan kriteria usia.

2. Faktor yang menjadi kendala PPDB dengan sistem zonasi diantaranya Sekolah favorit masih terbatas,Pemerataan kualitas pendidikan yang masih timpang dan Kurangnya sosialisasi dari pemerintah. Pengaturan sistem zonasi dalam PPDB yang diatur berdasarkan Peraturan Menteri Pendidikan Dan Kebudayaan Republik Indonesia Nomor 1 Tahun 2021 tepatnya Pasal 31, bertentangan dengan peraturan diatasnya yaitu PP RI No 13 Tahun 2015 tepatnya Pasal 68 huruf b yang menetapkan bahwa hasil ujian nasional digunakan sebagai dasar untuk pertimbangan seleksi masuk jenjang pendidikan berikutnya, yang mana peraturan pemerintah ini merupakan penjabaran dari Undang-Undang Nomor 20 Tahun 2003 tentang Sistem Pendidikan Nasional.

\section{H. Saran}

1. Bagi Pemerintah harus melakukan evaluasi berlanjut guna menyempurnakan sistem zonasi yang telah menjadi kebijakan pemerintah.

2. Bagi Pemerintah dan Legislatif, Peraturan Menteri Pendidikan Dan Kebudayaan Republik Indonesia Nomor 1 Tahun 2021 harus dicabut, atau perlu dikaji ulang dan disesuaikan dengan peraturan diatasnya agar tercipta harmonisasi peraturan perundang-undangan. 


\section{DAFTAR PUSTAKA}

\section{A. Buku :}

Azyumardi Azra, Pembaharuan Pendidikan Islam, dalam Marwan Saridjo, Bunga Rampai Pendidikan Agama Islam, Amisco, Jakarta. 1996.

Bambang Sunggono, Metode Penelitian Hukum PT. Raja Grafindo Persada, Jakarta, 2002.

Hans Kelsen, General Theory of Law State Russell \& Russell,New York,1945.

Ibrahim, Johnny. Teori dan metodologi penelitian hukum normatif. Bayumedia Publishing, Malang,2006.

\section{B. Peraturan Perundang-undangan}

Undang-Undang Dasar Negara Republik Indonesia Tahun 1945.

Undang-Undang Republik Indonesia Nomor 20 tahun 2003 tentang sistem pendidikan nasional

Peraturan Pemerintah Republik Indonesia Nomor 13 Tahun 2015 Tentang Perubahan Kedua Atas Peraturan Pemerintah Nomor 19 Tahun 2005 Tentang Standar Nasional Pendidikan

Peraturan Menteri Pendidikan Dan Kebudayaan 1 Tahun 2021 tentang Penerimaan Peserta Didik Baru Pada Taman Kanak-Kanak, Sekolah Dasar, Sekolah Menengah Pertama, Sekolah Menengah Atas, Dan Sekolah Menengah Kejuruan

\section{Sumber Lain:}

\section{Jurnal, Skripsi dan Makalah}

Abdul Khakim, Hak Asasi Manusia Dalam Perspektif Pendidikan Islam, Jurnal Evaluasi Pasuruan, Vol.2, No. 1, Maret 2018.

Agil Nanggala, Analisis Wacana Pembaharuan Kebijakan Zonasi Menteri Pendidikan Dan Kebudayaan Nadiem Makarim Sebagai Solusi Pemerataan Pendidikan Di Indonesia, Jurnal Pendidikan Kewarganegaraan Undiksha Vol. 8 No. 2 Mei, 2020.

Hendrawansyah dan Zamroni, Evaluasi Kebijakan Sistem Zonasi Dalam Penerimaan Siswa Baru Sekolah Menengah Atas, Jurnal Kependidikan, Volume 4, Nomor 1, 2020. 
I Putu Andika Pratama dan Ketut Suardita, Pengaturan Penerimaan Peserta Didik Baru Melalui Jalur Zonasi Sekolah, Jurnal Jurnal Kertha Patrika, Vol. 41, No. 3 Desember 2019.

Muammar, Problematika Penerimaan Peserta Didik Baru (PPDB) Dengan Sistem Zonasi Di Sekolah Dasar (SD) Kota Mataram, Jurnal PGMI ẽlMidad. uinmataram. Vol. 11 No.1 Juni 2019.

Mujianto Solichin, Imama Kutsi, Implementasi Permendikbud Nomor 14 Tahun 2018 tentang Penerimaan Peserta Didik Baru Berbasis Sistem Zonasi pada Tingkat Madrasah Ibtidaiyah/Sekolah Dasar di Kecamatan Jombang, Jurnal Manajemen dan Pendidikan Islam, Vol. 5, No. 1, Juni 2019.

Tri Mulyani, Dewi Tuti Muryati, Analisis Yuridis Mengenai Sistem Zonasi Dalam Penerimaan Peserta Didik Baru, Jurnal USM Law Review, Universitas Semarang, Vol 3 No 1 Tahun 2020.

\section{Internet}

alf, Mekanisme Aturan PPDB 2020,https:// edukasi. sindonews.com/ read/ 36103/144/ mekanisme-aturan-ppdb-2020-1589861113?showpage= all\#: :text=Apa\%20Itu\% 20Jalur\%20 Zonasi\&text= Jalur\% 20sistem $\% 20$ zonasi\%20merupakan\%20jalur,SMP\%2C\%20 serta\%20SMA\% 2FSMK. Diakses pada tanggal 21/01/2020

M. Armen Lukman, Ketidakadilan Dalam Penerimaan Peserta Didik Baru (PPDB) 2020 dan Langkah Hukum yang Dapat Dilakukan, https:// kliklegal.com/ketidakadilan-dalam-penerimaan-peserta-didik-baruppdb-2020-dan-langkah-hukum-yang-dapat-dilakukan/diakses pada tanggal $21 / 1 / 2020$ 